\title{
A METHOD OF RISK AND SAFETY ASSESSMENT DURING THE SHIP SALVAGE USING THE HAZARD, RELEASE AND CONSEQUENCE ANALYSIS
}

\section{METODA OCENY RYZYKA I BEZPIECZEŃSTWA W CZASIE RATOWANIA STATKU USZKODZONEGO PRZY UŻYCIU ANALIZY ZAGROŻEŃ, UWOLNIEŃ I KONSEKWENCJI WYPADKU}

\author{
Mirosław Gerigk ${ }^{1}$
}

(1) Gdańsk University of Technology

80-952 Gdańsk ul. G.Narutowicza 11/12

e-mail: (1) mger@pg.gda.pl

\begin{abstract}
The paper concerns the ship salvage. The existing methods are very difficult to apply for the salvage purposes. A method based on the risk and safety assessment of ships in damaged conditions is presented in the paper. The level of risk is the measure of safety. The method applies the ship performance approach together with the risk assessment. The risk analysis is based on application of the matrix type risk model. The risk model enables to consider many possible scenarios of an accident using the Event Tree Analysis ETA concerning the hazards, releases and consequences.
\end{abstract}

Keywords: safety of ships, ship salvage, risk assessment

Streszczenie: Artykut dotyczy ratowania statków. Obecne metody oceny bezpieczeństwa statku w stanie uszkodzonym trudno zastosować w czasie wypadku. $W$ artykule opisano metodę oceny ryzyka i bezpieczeństwa statku uszkodzonego. Miara bezpieczeństwa statku jest poziom ryzyka. Zastosowano podejście oparte na ocenie zachowania statku $i$ ocenie ryzyka wypadku. $W$ analizie ryzyka wykorzystano macierzowy model ryzyka, umożliwiajacy rozpatrywanie wielu scenariuszy, w oparciu o analize zagrożeń, uwolnień $i$ konsekwencji wypadku.

Słowa kluczowe: bezpieczeństwo statków, ratowanie statków, ocena 


\section{Introduction}

The paper presents a few problems regarding a method of risk and safety assessment during the ship salvage using the hazard, release and consequence analysis. The entire research is connected with development of a performance-oriented risk-based method for assessment of safety of ships in damaged conditions (Gerigk, 2010).

The current methods of assessment of safety of ships in damaged conditions are more or less based on the regulations included in the harmonized SOLAS convention (Chapter II-1) (IMO, 2005; IMO, 2008). These methods are difficult to apply for the salvage purposes. It follows from the different reasons. Between them are as follows. These methods are prescriptive in their character. Some of these methods are based on a probabilistic approach to safety but some of them are semi-probabilistic in their nature. These methods do not take into account all the possible hazards and scenarios of accidents. These methods are more devoted to the design aspects than operational one. Application of some of these methods to certain types of ships e.g. car-carriers, ro-ro vessels or passenger ships may even lead to insufficient level of ship safety or provide unnecessary design restrictions what can substantially decrease the ship safety in operation.

The following methods relay on the SOLAS convention and may be considered for application for the salvage purposes.

The first method is based on the holistic risk model for the assessment of safety of ships in damaged conditions as follows (Jasionowski \& Vassalos, 2006; Skjong et al., 2006):

$$
\mathrm{R}=\mathrm{P}_{\mathrm{c}} \times \mathrm{P}_{\mathrm{c} / \text { fdpe }} \times \mathrm{P}_{\mathrm{c} / \text { fdpe/ns }} \times \mathrm{P}_{\mathrm{c} / \text { fdpe/ns/tts }} \times \mathrm{C}
$$

where:

$\mathrm{P}_{\mathrm{c}}$ - probability of collision (hazard); $\mathrm{P}_{\mathrm{c} / \mathrm{fdpe}}$ - probability of flooding having the ship hit from given direction at data position with given extent conditional on collision; $\mathrm{P}_{\mathrm{c} / \mathrm{fdpe} / \mathrm{ns}}$ - probability of not surviving conditional on having flooding when the ship is hit from given direction at data position with given extent conditional on collision; $\mathrm{P}_{\mathrm{c} / \text { fdpe/ns/ts }}$ - probability of given time to sink conditional on not surviving the conditional on having flooding when the ship is hit from given direction at data position with given extent conditional on collision; $\mathrm{C}$ - consequences regarding the fatalities, property (cargo, ship) and/or environment. 
The second method is based on the casualty threshold, time to capsize and return to port concepts, where the basic ship safety objectives have been divided into three categories (Vassalos, 2007):

- category I - vessel remains upright and afloat and is able to return to port under own power (RTP - Return To Port);

- category II - vessel remains upright and afloat but unable to return to port under own power and is waiting for assistance (WFA - Waiting For Assistance);

- category III - vessel likely to capsize/sink and abandonment of the ship may be necessary (AS - Abandonment of the Ship).

The third method is based on a concept of an absolute survivability where the Safe Return to Port (SRtP) attained subdivision index A SRtP $_{\text {should be }}$ calculated according to the ship residual stability characteristics (IMO, 2009):

$$
\mathrm{A}_{\mathrm{SRtP}}=0,4 \mathrm{~A}_{\mathrm{SRtP}, \mathrm{s}}+0,4 \mathrm{~A}_{\mathrm{SRtP}, \mathrm{p}}+0,2 \mathrm{~A}_{\mathrm{SRtP}, 1}
$$

where the subdivision indices $A_{S R t P, s}, A_{S R t P, p}$ and $A_{S R t P, 1}$ for the subdivision (s), partial (p) and light (1) ship loading conditions. The $A_{S R t P, s}, A_{S R t P, p}$ and $\mathrm{A}_{\mathrm{SR} P \mathrm{P}, 1}$ indices should be calculated according to the following formula:

$$
\mathrm{A}_{\mathrm{SRtP}, \mathrm{lc}}=\sum_{i=1}^{n} \mathrm{p}_{\mathrm{i}} \mathrm{S}_{\mathrm{SRtP}, \mathrm{i}}
$$

where $1 \mathrm{c}-$ loading index $(\mathrm{lc}=\mathrm{s}, \mathrm{p}, 1) ; \mathrm{p}_{\mathrm{i}}$ - probability that only the compartment or group of compartments under consideration may be flooded, as defined in regulation 7-1 (IMO, 2005; IMO, 2008); $\mathrm{s}_{\mathrm{SRtP}, \mathrm{i}}$ probability of survival after flooding the compartment or group of compartments under consideration, in the final stage of flooding only, as defined in (IMO, 2009).

\section{Ship salvage}

The ship accidents at sea may not only lead to the loss of life, loss of properties (ship and cargo) but also to the pollution of environment. The modern approach to safety of seaborne transportation requires to apply the so-called life-circle approach by integrating the design for safety, safe operation and safe salvage methods. Most of the salvage activities have 
been associated with using the rules of thumb without a support based on the safety assessment process. The effective and safe ship salvage requires to develop the methods, models and tools for the assessment of risk and safety of ships in damaged conditions.

A method of risk and safety assessment of ships in damaged conditions should enable to assess a ship survivability at each stage of flooding including the preliminary, intermediate and final stages of flooding. Such an assessment is necessary to predict any further deterioration of the damage condition. It may be connected with further flooding of compartments and ship listing increase. This assessment also regards predicting how long it would take the ship to capsize or sink. If the ship survives flooding (a ship remains upright (or heeled) and afloat) and is unable to return to port under own power it is necessary to solve the problems associated with the towing when waiting for an assistance. The number of towing points and towing speed in the calm and rough weather conditions should be evaluated. During the towing the risk and safety assessment of the ship should be permanently conducted.

The factors affecting the safety of a ship in damaged conditions may be technical, environmental, organizational or human (Gerigk, 2010). There is an influence of the so-called life circle factors as well. It means that the risk and safety of the ship in damage conditions during the salvage depends on design and operation (Maritime Magazine, 2007; Mohaghegh \& Mosleh, 2009; Shipbuilding Magazine, 2005).

\section{A method of risk and safety assessment during the ship salvage}

The methodology were the risk-based design is a formalized design methodology that integrates the risk analysis in the design process with the prevention/reduction of risk embedded as a design objective, along standard design objectives was introduced by Vassalos and the others (Skjong et al., 2006; SSRC, 2009; Vassalos, 2006). The methodology which applies a holistic approach that links the risk prevention/reduction measures to ship performance and cost by using relevant tools to address ship design and operation.

The proposed method is a kind of performance-oriented risk-based procedure which enables the risk and safety assessment during the ship salvage using the hazard, release and consequence analysis. 
Within the method the holistic approach to safety assessment of ships has been applied. It is based on application of a risk model which includes all the possible scenarios of events during an accident. The method takes into account an influence of design and operational factors on safety and safety management related factors as well. The method is based on implementation of the system integrated approach to safety, elements of Formal Safety Assessment FSA, ship performance-oriented approach and risk-based approach to safety. For the ship performance evaluation the statistics, investigations using the physical models and numerical simulation techniques can be applied. The ship performance evaluation enables to determine the consequences and risk of each accident scenario. The safety objective is to achieve an adequate level of risk by reducing the risk if necessary. Providing a sufficient level of safety based on the risk assessment is the main objective. It is either the design, operational or organizational objective. Then, safety is not a limitation any more, existing in the regulations. The measure of safety of a ship in damaged conditions is the level of risk.

The proposed method may be used at any ship's life circle, including safety assessment of the ship during a catastrophe. Some elements of the method can be used for safety assessment of different means and systems of seaborne transportation. In the future the method can be useful in elaboration of a new methodology of safety assessment of ships, which bases on the application of risk analysis.

The safety case considered regards the safety of a ship in damaged conditions when the ship skin is damaged due to either a collision, grounding, stranding or another reason.

The method is based on the following steps: setting the objectives, hazard identification, scenarios development, risk assessment, risk control (prevention, reduction), selection of designs (operational procedures) that meet the objectives. The structure of the method is presented in Figure 1 (Gerigk, 2010).

\section{The risk analysis using the matrix type risk model}

The risk and safety assessment during the ship salvage starts from the modeling of the risk contribution tree for three major hazards from the salvage point of view: collision, stranding and grounding. For each hazard a separate event tree was modeled using the Event Tree Analysis ETA. 


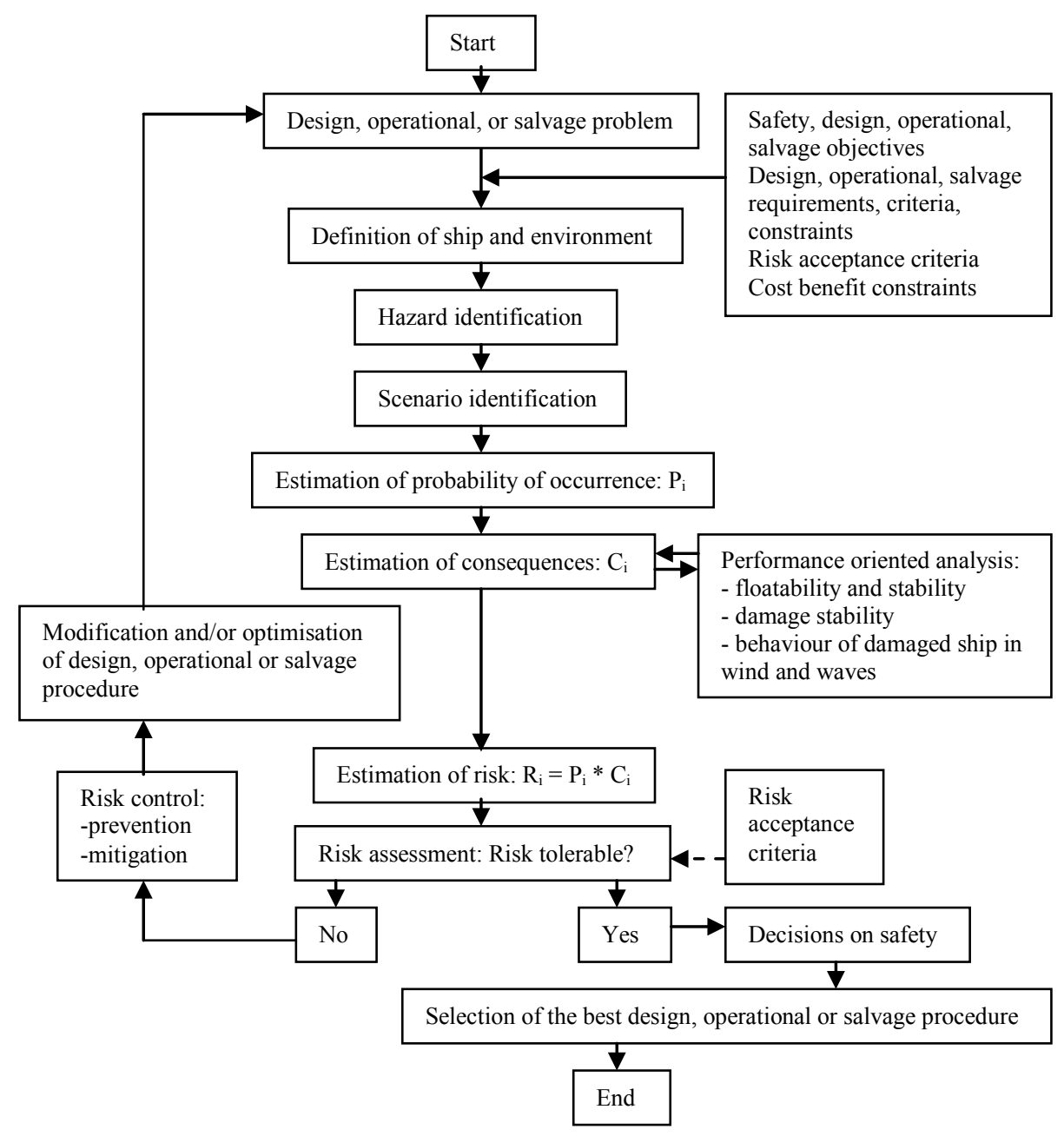

Fig. 1 Logical structure of the risk-based design system (method)

Generally, sixteen safety functions have been used for each event tree from the ship salvage point of view. Between them are as follows (Gerigk, 2010):

-function 1 - avoiding the hazard, -function 2 - hull skin damage (flooding), -function 3 - position and extension of damage, -function 4 - equalization of the ship heel at the preliminary stage of flooding,

-function 5 - loss of the ship stability at the preliminary stage of flooding, 
-function 6 - loss of the ship stability during the intermediate stages (and phases) of flooding,

-function 7 - loss of the ship stability at the final stage of flooding, -function 8 - loss of the ship floatability at the final stage of flooding, -function 9 - ship is waiting for assistance, -function 10 - ship returns to port under own power, -function 11 - ship returns to port by tow, -function 12 - ship is continuing the mission, -function 13 - mustering and abandonment of the ship (evacuation), -function 14 - SAR action, -function 15 - fire and/or explosion, -function 16 - emergency cargo unloading (pollution of the environment).

It is important to notice that each event tree may have a dynamical character. A basic event tree for the salvage is presented in Figure 2.

The holistic approach to ship safety has been applied. According to this approach two major assumptions have been done. First that the system failures can be either the hardware, software, organizational or human failures. The second assumption concerns the holistic risk model to be applied for assessment of safety of ships in damaged conditions.

The risk associated with the different hazards and scenario development was estimated according to the well known general formulae:

$$
\mathrm{R}_{\mathrm{i}}=\mathrm{P}_{\mathrm{i}} \times \mathrm{C}_{\mathrm{i}}
$$

where $\mathrm{P}_{\mathrm{i}}$ - probability of occurrence of a given hazard; $\mathrm{C}_{\mathrm{i}}$-consequences following the occurrence of the data hazard and scenario development, in terms of fatalities, injuries, property losses and damage to the environment.

The risk model may be divided into four different modules depending on the losses regarding the human fatalities (HF), cargo and ship losses (CS), environment pollution (E) and financial losses (\$) as follows:

$$
\begin{aligned}
& \mathrm{R}=\mathrm{Pc} \mathrm{Pc} / \text { fdpe Pc/fdpe/ns Pc/fdpe/ns/tts } \times \mathrm{CHF} / \mathrm{C} \\
& \mathrm{R}=\mathrm{Pc} \mathrm{Pc} / \text { fdpe Pc/fdpe/ns Pc/fdpe/ns/tts } \times \mathrm{CCS} / \mathrm{C} \\
& \mathrm{R}=\mathrm{Pc} \mathrm{Pc/fdpe} \mathrm{Pc/fdpe/ns} \mathrm{Pc/fdpe/ns/tts} \times \mathrm{CE} / \mathrm{C} \\
& \mathrm{R}=\mathrm{Pc} \mathrm{Pc/fdpe} \mathrm{Pc/fdpe/ns} \mathrm{Pc/fdpe/ns/tts} \times \mathrm{C} \text { /C }
\end{aligned}
$$




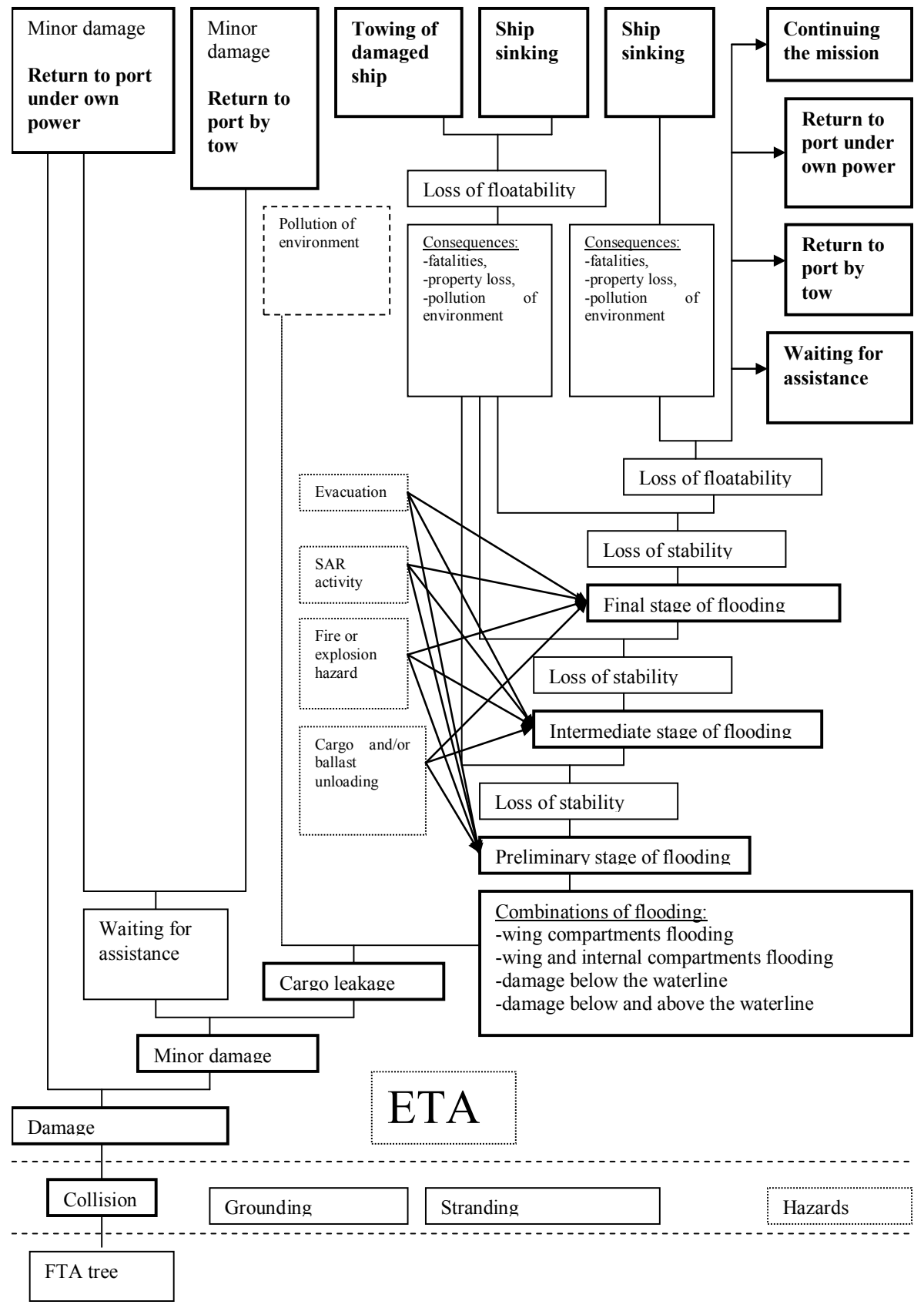

Fig. 2 A basic event tree for the salvage purposes. 
The risk analysis requires to calculate the conditional probabilities regarding the initial events $\mathrm{ZI}_{\mathrm{i}}$, major events (hazards) $\mathrm{ZG}_{\mathrm{j}}$, intermediate events $\mathrm{ZP}_{\mathrm{k}}$ and final events $Z_{1}$ which can be treated as consequences. The basic mathematical formula are as follows (Gerigk, 2010):

$\mathrm{P}(\mathrm{ZI})=\mathrm{P}\left(\mathrm{ZI}_{\mathrm{i}}\right)=\left[\mathrm{P}\left(\mathrm{ZI}_{1}\right), \mathrm{P}\left(\mathrm{ZI}_{2}\right), \ldots, \mathrm{P}\left(\mathrm{ZI}_{\mathrm{n}}\right)\right]$ for $\mathrm{i}=1$ to $\mathrm{n}$

$\mathrm{P}\left(Z_{\mathrm{j}} / \mathrm{ZI}_{\mathrm{i}}\right)=\left[\begin{array}{cccc}\mathrm{P}\left(Z_{\mathrm{G}} / \mathrm{ZI}_{1}\right) & \mathrm{P}\left(\mathrm{ZG}_{2} / \mathrm{ZI}_{1}\right) & \ldots & \mathrm{P}\left(\mathrm{ZG}_{\mathrm{m}} / \mathrm{ZI}_{1}\right) \\ \mathrm{P}\left(\mathrm{ZG}_{1} / \mathrm{ZI}_{2}\right) & \mathrm{P}\left(\mathrm{ZG}_{2} / \mathrm{ZI}_{2}\right) & \ldots & \mathrm{P}\left(\mathrm{ZG}_{\mathrm{m}} / \mathrm{ZI}_{2}\right) \\ \ldots & \ldots & \ldots & \ldots \\ \mathrm{P}\left(\mathrm{ZG}_{1} / \mathrm{ZI}_{\mathrm{n}}\right) & \mathrm{P}\left(\mathrm{ZG}_{2} / \mathrm{ZI}_{\mathrm{n}}\right) & \ldots & \mathrm{P}\left(\mathrm{ZG}_{\mathrm{m}} / \mathrm{ZI}_{\mathrm{n}}\right)\end{array}\right]$

for $\mathrm{j}=1$ to $\mathrm{m}$.

$\mathrm{P}\left(\mathrm{ZP}_{\mathrm{k}} / \mathrm{ZG}_{\mathrm{j}}\right)=\left[\begin{array}{cccc}\mathrm{P}\left(\mathrm{ZP}_{1} / \mathrm{ZG}_{1}\right) & \mathrm{P}\left(\mathrm{ZP}_{2} / \mathrm{ZG}_{1}\right) & \ldots & \mathrm{P}\left(\mathrm{ZP}_{\mathrm{m} 1} / \mathrm{ZG}_{1}\right) \\ \mathrm{P}\left(\mathrm{ZP}_{1} / \mathrm{ZG}_{2}\right) & \mathrm{P}\left(\mathrm{ZP}_{2} / \mathrm{ZG}_{2}\right) & \ldots & \mathrm{P}\left(\mathrm{ZP}_{\mathrm{m} 1} / \mathrm{ZG}_{2}\right) \\ \ldots & \ldots & \ldots & \ldots \\ \mathrm{P}\left(\mathrm{ZP}_{1} / \mathrm{ZG}_{\mathrm{m}}\right) & \mathrm{P}\left(\mathrm{ZP}_{2} / \mathrm{ZG}_{\mathrm{m}}\right) & \ldots & \mathrm{P}\left(\mathrm{ZP}_{\mathrm{m} 1} / \mathrm{ZG}_{\mathrm{m}}\right)\end{array}\right]$

for $\mathrm{k}=1$ to $\mathrm{m} 1$.

$\mathrm{P}\left(\mathrm{ZK}_{1} / \mathrm{ZP}_{\mathrm{k}}\right)=\left[\begin{array}{cccc}\mathrm{P}\left(\mathrm{ZK}_{1} / \mathrm{ZP}_{1}\right) & \mathrm{P}\left(\mathrm{ZK}_{2} / \mathrm{ZP}_{1}\right) & \ldots & \mathrm{P}\left(\mathrm{ZK}_{\mathrm{m} 2} / \mathrm{ZP}_{1}\right) \\ \mathrm{P}\left(\mathrm{ZK}_{1} / \mathrm{ZP}_{2}\right) & \mathrm{P}\left(\mathrm{ZK}_{2} / \mathrm{ZP}_{2}\right) & \ldots & \mathrm{P}\left(\mathrm{ZK}_{\mathrm{m} 2} / \mathrm{ZP}_{2}\right) \\ \ldots & \ldots & \ldots & \ldots \\ \mathrm{P}\left(\mathrm{ZK}_{1} / \mathrm{ZP}_{\mathrm{m} 1}\right) & \mathrm{P}\left(\mathrm{ZK}_{2} / \mathrm{ZP}_{\mathrm{m} 1}\right) & \ldots & \mathrm{P}\left(\mathrm{ZK}_{\mathrm{m} 2} / \mathrm{ZP}_{\mathrm{m} 1}\right)\end{array}\right]$

for $1=1$ to $\mathrm{m} 2$.

Because of the above mathematical model used the entire risk model is called as the matrix type risk model. The risk model enables to consider many possible scenarios of an accident using the event tree like presented in Figure 2.

In the case when the release events occur the probability of occurring the given consequences $\operatorname{PoC}\left(C_{i}\right)$ can be calculated as follows (Gerigk, 2010):

$\operatorname{PoC}\left(\mathrm{C}_{\mathrm{i}}\right)=\sum_{\mathrm{j}=1}^{\mathrm{Nzd}} \mathrm{P}\left(\mathrm{C}_{\mathrm{i}}, \mathrm{ZD}_{\mathrm{j}}\right)=\sum_{\mathrm{j}=1}^{\mathrm{Nzd}} \mathrm{P}\left(\mathrm{C}_{\mathrm{i}} / \mathrm{ZD}_{\mathrm{j}}\right) \mathrm{P}\left(\mathrm{ZD}_{\mathrm{j}}\right)$

where Nzd - number of possible releases (additional events) for the given accident scenario; $\mathrm{P}\left(Z \mathrm{Z}_{\mathrm{j}}\right)$ - probability of occurrence of a given release; 
$\mathrm{P}\left(\mathrm{C}_{\mathrm{i}}, \mathrm{ZD}_{\mathrm{j}}\right)$ - probability of occurring the given consequences $\mathrm{C}_{\mathrm{i}}$ conditional on occurrence of the given release $\mathrm{ZD}_{\mathrm{j}}$.

The typical releases may be as follows: water on deck, air cushions, cargo leakage, additional heeling moments, passenger behavior.

The risk model presented in (4),(5),(6),(7) and (8) is different from the model presented by Skjong et al. (Jasionowski \& Vassalos, 2006; Skjong et al., 2006; SSRC, 2009; Vassalos, 2006) as it does not use the conditional probability of sinking given by the $\mathrm{P}_{\text {sink }}{ }^{=} 1$-A complement probability of the attained subdivision index $\mathrm{A}$.

An example a ship performance data regarding the ship roll function in time domain and a concept of the ALARP risk evaluation criteria is presented in Figure 3.

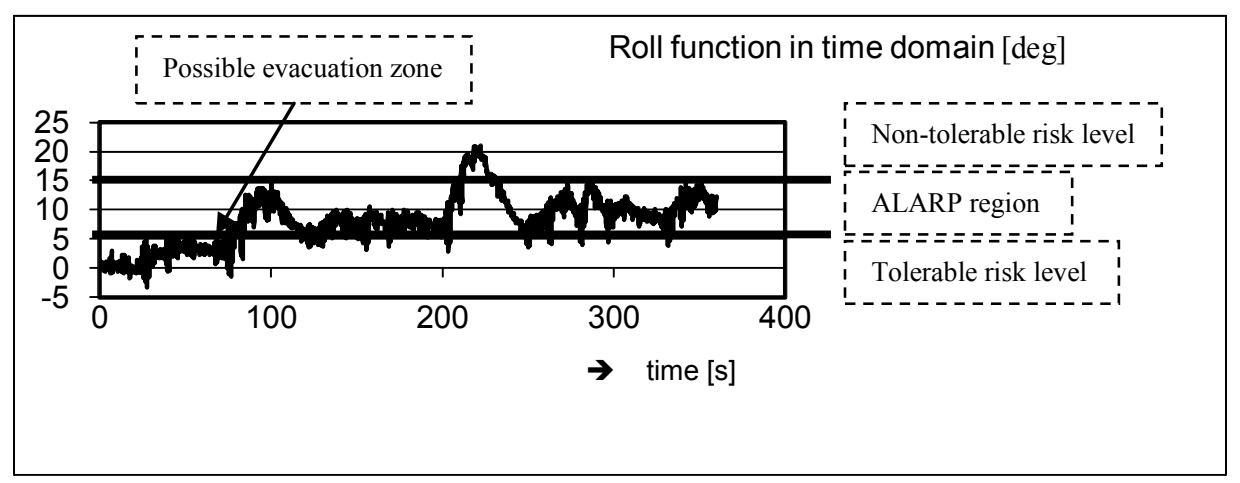

Fig. 3 An example a ship performance data regarding the ship roll function in time domain and a concept of the ALARP risk evaluation criteria

\section{Conclusions}

Some elements of the method of risk and safety assessment of ships in damaged conditions for the salvage purposes are presented in the paper. The level of risk is the measure of safety during salvage.

The current research regarding the method is associated with further developing the performance-oriented and risk-based models. From the practical point of view the research should bring a model for the computer simulation of the ship salvage process. This may be a helpful tool for a decision support system during the real salvage at sea. Despite the salvage- 
oriented purposes the method may be implemented in design and in operation.

\section{Acknowledgements}

The author would like to express his kind gratitude to the Ministry of Science and High Education, for the support to carry out the investigations on novel solutions for assessment of safety of ships.

\section{References}

1. Gerigk, M. Kompleksowa metoda oceny bezpieczeństwa statku w stanie uszkodzonym z uwzględnieniem analizy ryzyka, monografie 101, Wydawnictwo Politechniki Gdańskiej, Gdańsk 2010.

2. IMO. 2005. Report of the Maritime Safety Committee on Its Eightieth Session, MSC 80/24/Add.1, London, 2005.

3. IMO. 2008. http://www.imo.org.

4. IMO. 2009. Stability and Seakeeping Characteristics of Damaged Passenger Ships in a Seaway When Returning to Port by Own Power or Under Tow, A survey of residual stability margin, Submitted by Germany, SLF 52/8/1, London, 26 October 2009.

5. Jasionowski, A. \& Vassalos, D. 2006. Conceptualising Risk, Proceedings of the 9th International Conference on Stability of Ships and Ocean Vehicles STAB 2006, Rio de Janeiro, 25-29 September 2006.

6. Maritime Magazine (Nasze Morze, in Polish). 2007. What may happen to the Baltic Sea (Co z tym Battykiem, in Polish)? Volume 12 (24), December 2007.

7. Mohaghegh, Z. \& Mosleh, A. 2009. Incorporating organizational factors into probabilistic risk assessment of complex socio-technical systems: Principles and theoretical foundations, Journal of Safety Science, Vol. 47, 2009, pp. 1139-1158.

8. Shipbuilding Magazine (Budownictwo Okrętowe, in Polish). 2005. It can be a catastrophe (Może być strasznie, in Polish). Volume 3 (548), March 2005.

9. Skjong R. \& Vanem E. \& Rusas S. \& Olufsen O. 2006. Holistic and Risk Based Approach to Collision Damage Stability of Passenger 
Ships, Proceedings of the $9^{\text {th }}$ International Conference on Stability of Ships and Ocean Vehicles STAB 2006, Rio de Janeiro, 25-29 September 2006.

10. SSRC. 2009. http://www.ssrc.na-me.ac.uk

11. Vassalos, D. 2006. Passenger Ship Safety: Containing the Risk, Marine Technology, Vol. 43, No. 4, October 2006, pp. 203-213.

12. Vassalos, D. 2007. Safe return to port, Seminar for the $50^{\text {th }}$ session of the IMO SLF Sub-Committee, London, May 2007.

Miroslaw Gerigk PhD. Eng. Gdansk University of Technology, Gdansk, Senior lecturer, specjalisation: ship and ocean engineering design, ship hydromechanics, ship safety, safety of sea transportation, safety of ships in damaged conditions. Over fifty publications in field. 